\title{
Terapi Kreasi Seni Menggambar Terhadap Kemampuan Melakukan Menggambar Bentuk pada Pasien Harga Diri Rendah
}

\author{
Muhammad Mulyawan', Marisca Agustina ${ }^{2}$ \\ ${ }^{1,2}$ Program Studi Ilmu Keperawatan \\ Sekolah Tinggi Ilmu Kesehatan Indonesia Maju \\ Jln. Harapan Nomor 50, Lenteng Agung - Jakarta Selatan 12610 \\ Email: ${ }^{1}$ Muhammadmulyawan0@gmail.com, ${ }^{2}$ Marisca_duff@yahoo.com
}

\begin{abstract}
Abstrak
Terapi kreasi seni menggambar dapat dijadikan salah satu terapi modalitas untuk pasien harga diri rendah dalam melakukan kegiatan. Tujuan penelitian ini untuk mengetahui pengaruh terapi kreasi seni menggambar terhadap kemampuan melakukan kegiatan pada pasien harga diri rendah. Desain penelitian ini menggunakan quasy eksperimental dengan jenis perhitungan paired sample $t$ test. penelitian ini dilakukan di RSJ Dr. Soeharto Heerdjan dengan jumlah populasi sebanyak 33 responden dan menggunakan total sampling. Sampel pada penelitian ini sejumlah 33 pasien harga diri rendah.Alat pengumpulan data menggunakan lembar observasi. Dari hasil uji Univariat menunjukan bahwa sebelum dilakukan terapi kreasi seni menggambar sebagian besar tidak mampu $(60,6 \%)$ dan setelah dilakukan terapi kreasi seni menggambar sebagian besar mampu $(84,8 \%)$. Dari hasil uji paired sample t test didapatkan nilai $p$ value .000 dimana nilai $\mathrm{p}<0,05$. maka dapat diartikan Ha diterima dan Ho di tolak dan ada pengaruh terapi kreasi seni menggambar terhadap kemampuan melakukan kegiatan pada pasien harga diri rendah di Rumah Sakit Jiwa Dr. Soeharto Heerdjan Jakarta. Diharapkan perawat dapat memakai terapi kreasi seni menggambar agar pasien dapat mengingat aspek positif dan melakukan kegiatan secara mandiri.
\end{abstract}

Kata Kunci : Terapi kreasi seni menggambar, kemampuan melakukan kegiatan

\begin{abstract}
Therapy art draw creations could be one modality therapy for patients with low self-esteem in the activities. The purpose of this study is to determine the effect of therapy on the ability to draw artistic creation activity in patients with low self esteem. This research design using experimental quasy with paired sample $t$ kind of calculations performed in this test.penelitian RSJ Dr. Soeharto Heerdjan with a total population of 33 respondents and use total sampling. Samples in this study a total of 33 patients low self-esteem. Alat data collection using observation sheet. From the test results obtained paired sample t test $p$ value .000 where the value of $p<0.05$. it means Ha accepted and Ho is rejected and no therapeutic effect on the ability to draw artistic creation activity in patients with low self-esteem at the Mental Hospital Dr. Soeharto Heerdjan Jakarta. Expected nurses can draw artistic creations therapy that patients can remember the positive aspects and conduct activities independently.
\end{abstract}

Keywords $\quad$ : Art therapy drawing creation, ability to perform activities 


\section{Pendahuluan}

Gangguan jiwa adalah gejala atau pola dari tingkah laku psikologi yang tampak secara klinis yang terjadi pada seseorang dari berhubungan dengan keadaan stress (gejala yang menyakitkan) ketidakmampuan (gangguan pada suatu area atau lebih dari fungsi-fungsi penting) yang meningkatkan resiko terhadap kematian, nyeri ketidakmampuan atau kehilangan kebebasan yang penting dan tidak jarang respon tersebut dapat diterima pada kondisi tertentu. ${ }^{1}$

Harga diri rendah adalah perasaan tidak berharga, tidak berarti dan rendah diri yang berkepanjangan akibat evaluasi yang negatif terhadap diri sendiri atau kemampuan diri. Adanya perasaan hilang kepercayaan diri, merasa gagal karena tidak mampu mencapai keinginan sesuai dengan ideal diri. ${ }^{2}$

Gangguan harga diri rendah akan terjadi jika kehilangan kasih sayang, perlakuan orang lain yang mengancam dan hubungan interpersonal yang buruk. Harga diri meningkat bila diperhatikan/dicintai dan dihargai atau dibanggakan. Tingkat harga diri seseorang berada dalam rentang tinggi sampai rendah. Harga diri tinggi/positif ditandai dengan ansietas yang rendah, efektif dalam kelompok, dan diterima oleh orang lain. Individu yang memiliki harga diri tinggi menghadapi lingkungan secara aktif dan mampu beradaptasi secara efektif untuk berubah serta cenderung merasa aman sedangkan individu yang memiliki harga diri rendah melihat lingkungan dengan cara negatif dan menganggap sebagai ancaman. ${ }^{3}$

Upaya yang dapat dilakukan untuk meningkatkan kemampuan untuk melakukan kegiatan pada pasien yang mengalami harga diri rendah adalah dengan terapi kreasi seni ; menggambar yang merupakan salah satu bagian dari terapi lingkungan. Terapi lingkungan berkaitan erat dengan stimulasi psikologis seseorang yang akan berdampak pada kesembuhan fisik maupun psikologis seseorang yang akan berdampak pada kesembuhan baik pada kondisi fisik maupun psikologis seseorang. ${ }^{2}$

Terapi lingkungan dapat membantu pasien untuk mengembangkan rasa harga diri, mengembangkan kemampuan untuk berhubungan dengan orang lain, membantu mempercayai orang lain. Terapi lingkungan dapat dibagi menjadi 4 jenis yaitu : terapi rekreasi, terapi kreasi seni, pettherapy dan plantherapy. Jenis terapi lingkungan yang tepat diterapkan pada pasien harga diri rendah adalah yang pertama terapi rekreasi, tujuan dari terapi tersebut adalah agar pasien dapat melakukan kegiatan secara konstruktif dan menyenangkan, dan mengembangkan kemampuan hubungan sosial, yang kedua adalah terapi kreasi seni, dalam terapi kreasi seni terbagi menjadi empat bagian yaitu terapi menari, atau dance, terapi musik, terapi menggambar atau melukis dan terapi literature atau biblio. Keempat jenis terapi ini membantu pasien untuk mengkomunikasikan tentang perasaan - perasaan dan kebutuhan kebutuhannya, memberikan kesempatan pada pasien untuk mengekspresikan tentang apa yang terjadi dengan dirinya serta memberikan kesempatan pada pasien untuk mengembangkan wawasan diri dan bagaimana mengekspresikan pikiran dan perilaku sesuai dengan norma yang baik. ${ }^{2}$

Hasil penelitian yang dilakukan oleh Nasir dan Muhith pada tahun 2011 mengatakan $60 \%$ faktor yang menentukan faktor kesehatan seseorang adalah kondisi lingkungannya. Terapi lingkungan yang terdiri dari terapi rekreasi, terapi kreasi seni dapat membantu pasien untuk mengembangkan rasa harga diri, mengembangkan kemampuan untuk melakukan kegiatan pada pasien dengan harga diri rendah. ${ }^{4}$

Jenis terapi lingkungan yang dapat diterapkan pada pasien harga diri rendah adalah terapi kreasi seni khususnya terapi stimulus menggambar tujuannya untuk mengekspresikan tentang apa yang terjadi dengan dirinya serta memberikan kesempatan melakukan kegiatan pada pasien untuk mengembangkan wawasan diri dan bagaimana melakukan sesuatu kegiatan dan perilaku sesuai dengan norma norma yang baik. ${ }^{2}$

Pada penelitian Ruspawan kemampuan mengekspresikan perasaan pada klien dengan harga diri rendah setelah diberikan terapi kreasi seni menggambar sebanyak dua kali menunjukan hasil 10 orang responden mampu 
mengekspresikan perasaan. Hal ini menunjukan terapi kreasi menggambar berpengaruh secara signifikan terhadap kemampuan mengekspresikan perasaan dan melakukan kegiatan pada klien harga diri rendah. ${ }^{5}$

Terapi kreasi seni menggambar diterapkan karena ada anggapan dasar bahwa pasien harga diri rendah akan dapat mengekspresikan perasaan melalui terapi lingkungan seni menggambar dari dengan ekspresi verbal. Dengan terapi kreasi seni menggambar perawat dapat mengkaji tingkat perkembangan, status emosional pasien dengan harga diri rendah, hipotesa diagnostiknya, serta melakukan intervensi untuk mengatasi masalah pasien harga diri rendah tersebut. Upaya yang dapat dilakukan untuk meningkatkan kegiatan pada pasien yang mengalami harga diri rendah adalah dengan terapi kreasi seni menggambar yang merupakan salah satu terapi lingkungan. Terapi kreasi seni menggambar berkaitan erat dengan stimulasi psikologis seseorang yang akan berdampak pada kesembuhan baik pada kondisi fisik maupun pskilogis seseorang. ${ }^{1}$

Hasil penelitian dari Hasriana (2011) dengan judul "Pengaruh Terapi lingkungan Terhadap Kemampuan Melakukan Kegiatan Pada pasien Harga Diri Rendah di Rumah Sakit Jiwa tampan provinsi Sulawesi selatan", menunjukan terapi kreasi seni menggambar memberikan memanfaat dalam mengatasi masalah gangguan jiwa dengan harga diri rendah. Dari hasil 'penelitian menunjukan adanya peningkatan melakukan kegiatan pada pasien dengan harga diri rendah kelompok intervensi (P-value < 0,05). Sedangkan pada kelompok kontrol kegiatan pada pasien harga diri rendah menurun $(\mathrm{P}$-value $>0,05)$. Terapi kreasi seni menggambar disarankan sebagai alternative dalam menangani pasien harga diri rendah di rumah sakit jiwa tampan riau.

Rumah Sakit Jiwa Soeharto Heerdjan jakarta merupakan rumah sakit jiwa di jakarta. Dibangun pada tahun 1876. Mengalami beberapa perubahan nama dari rumah sakit jiwa grogol dirubah dengan nama rumah sakit jiwa jakarta pada taun 1973, tahun 1993 dirubah dengan nama rumah sakit jiwa pusat jakarta, tahun 2003 dirubah lagi menjadi rumah sakit jiwa dr. Soehartoe herdjan. Di rs jiwa ini terdapat ruang rawat inap diantaranya : ruang rawat inap pasien laki - laki, yaitu elang, perkutut, merak, nuri dan puri nuri. Sementara pasien wanita dirawat dibeberapa ruang, yakni mawar, melati, kenanga dan cempaka. Terdapat pula sejumlah ruangan khusus untuk anak-anak dan remaja, penderita narkotika, alcohol, psikotropika dan zat adiktif (NAPZA). ${ }^{5}$

Berdasarkan data rekam medis di Rumah Sakit Jiwa Dr. Soehartoe Heerdjan jakarta periode januari sampai juni 2016, jumlah kunjungan pasien sebanyak 35.396 dan di ruang rawat inap sebanyak 1474. 10 besar diagnose penyakit pasien rawat inap diantaranya skizofrenia paranoid (766). Skizofrenia yang tak terinci (216), skizoektif, tipe manik (51), skizofrenia residual (37), psikotik akut (32), skizofrenia hebrefenik (28), GMO ( gangguan mental organic) (20), skizoafektif (20), skizoafektif, tipe depresi (18), dan harga diri rendah 33 orang. ${ }^{6}$

Hasil studi pendahuluan yang peneliti lakukan pada tanggal 05 September 2016 dengan metode wawancara terhadap 10 perawat yang bekerja diruang rawat inap rumah sakit jiwa Dr. Soeharto Heerdjan, didapati 10 perawat tersebut melakukan tindakan keperawatan yang dilakukan pada pasien harga diri rendah adalah cara mengajarkan mengidentifikasi kemampuan dan aspek positif yang dimiliki dan perawat mengatakan terapi lingkungan tidak pernah dilakukan diruangan tersebut karena yang biasa dipakai hanya terapi aktivitas kelompok (TAK) dalam satu minggu dilakukan 1 kali. Hasil observasi saat melakukan studi pendahuluan masih terlihat beberapa pasien gangguan jiwa dengan harga diri rendah yang menyendiri, tidak mampu berkonsentrasi, tidak bisa membuat keputusan dan tidak mampu melakukan kegiatan serta melamun di kamar. Pengolahan data dilakukan melalui proses editing data, koding, cleaning data dan prosecing.

Berdasarkan latar belakang diatas, maka peneliti tertarik melakukan penelitian yang berjudul "Pengaruh Terapi Kreasi Seni Menggambar Terhadap Kemampuan Melakukan Kegiatan Pada Pasien Harga Diri Rendah di Rumah Sakit Jiwa dr. Soehartoe Heerdjan Jakarta tahun 2016.

\section{Metode}

Penelitian yang digunakan adalah Quasi Experimental Pre-post without control karena peneliti memberikan perlakuan yang sama pada semua klien untuk diberikan intervensi terapi kreasi seni menggambar. Penelitian ini 
dilakukan untuk mengetahui kemampuan untuk melakukan kegiatan pada pasien harga diri rendah sebelum dan sesudah diberikan perlakuan atau intervensi berupa pemberian terapi kreasi seni menggambar.

Populasi adalah wilayah generalisasi yang terdiri dari objek dan subyek yang menjadi kuantitas dan karakteristik tertentu yang diterapkan oleh peneliti untuk dipelajari dan kemudian ditarik kesimpulannya. ${ }^{7}$ Populasi dalam penelitian ini adalah klien harga diri rendah diruang rawat inap elang 1, merak dan perkutut Rumah Sakit Jiwa Dr. Soehartoe Heerdjan Jakarta dengan jumlah pasien 33 orang.

Sampel adalah bagian dari jumlah dan karakteristik yang dimiliki oleh populas. $i^{7}$ Sampel penelitian ini adalah klien dengan gangguan harga diri rendah di ruang rawat inap elang 1, merak dan perkutut rumah sakit jiwa dr. Soehartoe heerdjan Jakarta dengan menggunakan total populasi 33 orang. Total populasi adalah teknik pengambilan sampel dimana jumlah sampel sama dengan populasi. ${ }^{7}$ Alasan mengambil jumlah populasi karena jumlah populasi kurang dari 100 dan seluruh populasi dijadikan sampel penelitian.

Data yang dipergunakan dalam penelitian ini dengan mempergunakan data demografi berupa no responden, jenis kelamin, usia, pendidikan, status perkawinan. Serta menggunakan data primer berupa lembar observasi. Lembar observasi yang dipergunakan sebelumnya diuji coba dulu. Jenis sakala pengukuran yang digunakan adalah skala ordinal. Isi lembar observasi berdasarkan strategi pelaksanaan (SP) I P pada pasien dengan gangguan jiwa harga diri

Hasil penelitian sebelum diberikan terapi kreasi seni menggambar sebagian besar tidak mampu $(60,6 \%)$. (Tabel 1)

Tabel 1.

Kemampuan Melakukan Kegiatan Sebelum Diberikan Terapi Kreasi Seni Menggambar $(\mathrm{N}=33)$

\begin{tabular}{ccc}
\hline $\begin{array}{l}\text { Kemampuan } \\
\text { melakukan } \\
\text { kegiatan }\end{array}$ & Jumlah & $\begin{array}{c}\text { Presentase } \\
(\%)\end{array}$ \\
\hline Mampu & 13 & 39,4 \\
Tidak mampu & 20 & 60,6 \\
\hline Total & 33 & 100,0 \\
\hline
\end{tabular}

rendah, terkait dengan pengaruh terapi kreasi seni menggambar.

Hasil asil penelitian menunjukan bahwa kemampuan melakukan kegiatan sesudah terapi kreasi seni menggambar sebagian besar mampu $(84,8 \%)$. (Tabel 2)

\section{Tabel 2.}

Kemampuan Melakukan Kegiatan Sesudah Diberikan Terapi Kreasi Seni Menggambar $(\mathrm{N}=33)$

\begin{tabular}{lcc}
\hline $\begin{array}{l}\text { Kemampuan } \\
\text { melakukan } \\
\text { kegiatan }\end{array}$ & Jumlah & Presentase (\%) \\
\hline Mampu & 28 & 84,8 \\
Tidak mampu & 5 & 15,2 \\
\hline Total & 33 & 100,0 \\
\hline
\end{tabular}

Hasil analisis bivariat menunjukan bahwa ada pengaruh kemampuan melakukan kegiatan pada pasien harga diri rendah sebelum terapi kreasi seni menggambar dan sesudah terapi kreasi seni menggambar didapatkan $p$ value $.000(\mathrm{p}<0,05)$. (Tabel 3)

\section{Tabel 3.}

Pengaruh Terapi Kreasi Seni Menggambar Terhadap Kemampuan Melakukan Kegiatan Pada Pasien Harga Diri Rendah $(\mathrm{N}=33)$

\begin{tabular}{ccccc}
\hline Variabel & Mean & SD & SE & P value \\
\hline $\begin{array}{c}\text { Sebelum } \\
\text { terapi } \\
\text { menggambar }\end{array}$ & 7.15 & 1.623 & .282 & \\
$\begin{array}{c}\text { Sesudah } \\
\text { terapi } \\
\text { menggambar }\end{array}$ & 13.12 & 3.426 & .596 & .000 \\
\hline
\end{tabular}

\section{Pembahasan}

\section{Kemampuan melakukan kegiatan responden harga diri rendah sebelum (pre) terapi kreasi seni menggambar}

Berdasarkan hasil penelitian menunjukan kemampuan melakukan kegiatan responden harga diri rendah sebelum diberikan terapi kreasi seni menggambar terbanyak adalah katagori tidak mampu $20(60,6 \%)$ dari 33 responden dan katagori tidak mampu $(39,4 \%)$. 
Penelitian Ruspawan (2011) tentang kemampuan melakukan kegiatan pada klien dengan harga diri rendah sebelum diberikan terapi kreasi seni Menggambar menunjukkan hasil dari 12 orang (100\%) responden klien harga diri rendah tidak ada yang mampu melakukan kegiatan. Kemampuan melakukan kegiatan pada klien dengan harga diri rendah setelah diberikan terapi kreasi seni Menggambar sebanyak dua kali menunjukkan hasil 10 orang $(83,3 \%)$ responden klien harga diri rendah mampu melakukan kegiatan dan 2 orang $(16,7 \%)$ responden tidak mampu melakukan kegiatan. Pengaruh terapikreasi seni Menggambar terhadap kemampuan melakukan kegiatan klien dengan harga diri rendah, hal ini menunjukkan terapi kreasi seni Menggambar berpengaruh secara signifikan terhadap kemampuan melakukan kegiatan pada klien dengan harga diri rendah. ${ }^{5}$

Abdee Pamungkas mengatakan pasien harga diri rendah harus diberikan faktor pencetus agar mampu melakukan kegiatan dan mampu secara mandiri menulis kegiatan dijadwal kegiatan harian. Harga diri rendah adalah perasaan tidak berharga, tidak berarti dan rendah diri yang berkepanjangan akibat evaluasi yang negatif terhadap diri sendiri atau kemampuan diri, agar mereka mampu mengevaluasi dirinya secara positif harus diberikan terapi untuk mengenali dirinya secara utuh. ${ }^{8,2}$

Yundini mengatakan bila pasien harga diri rendah tidak mampu melakukan kegiatan serta tidak mampu mengekspresikan perasannya dikarenakan pasien harga diri rendah selalu mempunyai perasaan negatif terhadap dirinya oleh karena itu harus diberikan terapi modalitas agar dapat mengekspresikan perasaan serta dapat menyebutkan kemampuan positif. Pasien dengan harga diri rendah tidak dapat menyebutkan kegiatan positif dan tidak dapat melakukan kegiatan jika belum diberikan terapi lingkungan. ${ }^{9,10}$

Hal ini sejalan dengan penelitian penelitian yang dilakukan Djaelani pada tahun 2009 yang menemukan bahwa ada pengaruh bermakna antara kemampuan melakukan kegiatan pada pasien dengan harga diri rendah sebelum diberikan terapi kreasi seni di Rumah Sakit Jiwa Daerah Surakarta. Berdasarkan kemampuan melakukan kegiatan pada pasien harga diri rendah yang belum diberikan terapi kreasi seni menggambar dari 29 responden yang tidak dapat melakukan kegiatan sebesar adalah 20 responden $(80,8 \%)$.

Menurut peneliti bahwa pasien harga diri rendah sebelum diberikan terapi kreasi seni menggambar tidak mampu melakukan kegiatan dan tidak mampu mengevaluasi secara positif terhadap diri sendiri karena pasien harga diri rendah selalu mengevaluasi negatif tentang dirinya, perlu diberikan reward terlebih dahulu untuk berinteraksi dengan pasien harga diri rendah agar dapat melakukan kegiatan selain itu pasien harga diri rendah mudah bosan sehingga tidak mampu menyebutkan kemampuan positif dan tidak mampu melakukan kegiatan. ${ }^{7}$

\section{Kemampuan melakukan kegiatan responden harga diri rendah sesudah (post) terapi kreasi seni menggambar}

Berdasarkan hasil penelitian diketahui bahwa kemampuan melakukan kegiatan responden harga diri rendah sesudah diberikan terapi kreasi seni menggambar terbanyak dengan katagori mampu yaitu 28 responden $(84,8 \%)$ dan katagori tidak mampu sesudah diberikan terapi kreasi seni menggambar 5 $(15,2 \%)$ dari 33 responden. Hal ini sesuai dengan teori donlon bahwa setelah pasien harga diri rendah diberikan terapi lingkungan yang diantaranya terapi kreasi seni menggambar maka pasien harga diri rendah mampu menyebutkan kegiatan positif serta dapat melakukan kegiatan secara mandiri dan mencatatnya kedalam buku jadwal kegiatan harian. ${ }^{14}$

Hal ini serupa dengan Penelitian Sukanada pada tahun 2010 penelitian yang berjudul pengaruh pelaksanaan terapi menggambar kelompok stimulasi sensori terhadap kemampuan berkomunikasi pada pasien harga diri rendah di RSJ Provinsi Bali dengan metode penelitian One-group pre-testposttest design, dan hasil yang didapat adalah sebagian besar pasien dengan harga diri rendah sesudah diberikan terapi kreasi seni menggambar mampu melakukan kegiatan. ${ }^{15}$

Ruspawan berpendapat bahwa kecenderungan pasien harga diri rendah sesudah diberikan terapi lingkungan dapat melakukan kegiatan dan dapat menghargai dirinya. Terapi lingkungan dapat dijadikan salah satu terapi modalitas untuk pasien harga diri rendah agar mampu melakukan kegiatan. ${ }^{5,11}$ 
Infokes mengatakan bahwa pasien dengan gangguan harga diri rendah dapat melakukan kegiatan secara mandiri dan tidak tidak dibantu ketika pasien tersebut mendapatkan terapi modalitas dan menemukan teman yang dapat menghargai dirinya. ${ }^{11}$

Nasir dan Muhith mengatakan seiring seringnya diberikan terapi modalitas pada pasien dengan harga diri rendah maka pasien akan mampu mengekspresikan perasaan dan mampu mengenal aspek positif serta mampu melakukan kegiatan secara mandiri sehingga dapat menghargai dirinya dan mempunyai perasaan yang berarti dan siap untuk kembali ke lingkungan masyarakat. ${ }^{4}$

Menurut peneliti bahwa pasien dengan harga diri rendah wajib diberikan terapi salah satunya terapi kreasi seni menggambar agar dapat melakukan kegiatan secara mandiri dan mampu mengevaluasi aspek positif terhadap diri sendiri, manfaat dari terapi kreasi seni menggambar adalah pasien dengan harga diri rendah dapat mengekspresikan perasaan dan dapat mengingat kegiatan positif yang dapat dilakukannya sehingga dapat melakukan kegiatan secara mandiri dan lebih percaya diri terhadap kemampuan diri.

\section{Pengaruh terapi kreasi seni menggambar terhadap kemampuan melakukan menggambar bentuk}

Didapatkan hasil pengaruh terapi kreasi seni menggambar terhadap kemampuan melakukan kegiatan pada pasien harga diri rendah di Rumah Sakit Jiwa Dr. Soeharto Heerdjan Jakarta terlihat jumlah responden 33 orang, nilai mean perbedaan skor antara sebelum dan sesudah adalah -5.970 dengan standard deviasi 3.107. Hasil uji statistik dengan menggunakan uji paired sample $t$ test didapatkan $p$ value .000 ( $\mathrm{p}<0,05)$, maka Ho di tolak dan ada pengaruh terapi kreasi seni menggambar terhadap kemampuan melakukan kegiatan pada pasien harga diri rendah di Rumah Sakit Jiwa Dr. Soeharto Heerdjan Jakarta.

Setyoadi dan Kushariadi, menyatakan bahwa terapi modalitas untuk pasien dengan gangguan harga diri rendah sangat penting karena untuk membangun salah satu karakter utama yaitu kepercayaan diri agar dapat kembali kepada lingkungan sekitar, untuk membangun kepercayaan diri pada pasien dengan harga diri rendah dapat dilakukan terapi modalitas yaitu salah satunya terapi dengan kreasi seni menggambar. ${ }^{11}$

Suknada menyatakan bahwa terapi kreasi stimulus menggambar adalah salah satu terapi yang dapat membangun kepercayaan pada pasien harga diri rendah, dapat membangun stimulus pada pasien sehingga dapat dilakukan dengan terapi kreasi seni menggambar maka pasien dengan harga diri rendah jauh lebih baik dibandingkan sebelum dilakukan terapi kreasi seni menggambar. ${ }^{12,13}$

Pasien dapat mengenali aspek positif yang dimilikinya dan dapat melakukan kegiatan secara mandiri jika diberikan terapi stimulus kreasi seni. ${ }^{14}$ Terapi kreasi seni menggambar dapat dijadikan terapi suportif untuk pasien dengan harga diri rendah sehingga pasien dapat mengevaluasi keadaan diri dengan baik dan dapat berimajinasi sehingga pasien dapat terhindar dari aspek negatif yang dimiliki. ${ }^{15,16}$

Hasriana juga menyatakan bahwa terapi kreasi seni menggambar dapat membangun karakter pasien dengan gangguan harga diri dan dapat memperbaiki stimulus sehingga pasien lebih percaya diri dan dapat mengevaluasi diri secara positif dan dapat mengingat kegiatan positif serta melakukan kegiatan secara mandiri tanpa dibantu. ${ }^{8}$

Penelitian ini sejalan dengan penelitian yang dilakukan Nugroho (2013) dengan judul penelitian "Pengaruh Terapi Kreasi Seni Menggambar Terhadap Perubahan Perilaku Menarik Diri di Rumah Sakit Jiwa Daerah Surakarta" dengan jumlah sampel pada penelitian ini berjumlah 73 orang. Hasil uji satistik paired $T$-test menunjukan bahwa ada pengaruh yang signifikan pada pengaruh terapi kreasi seni menggambar tethadap kemampuan melakukan kegiatan pasien harga diri rendah.pengaruh tersebut ditunjukkan dengan nilai $\mathrm{p}=.000(\mathrm{p}<0,05) .{ }^{13}$

Menurut peneliti terapi kreasi seni menggambar berpengaruh terhadap kemampuan melakukan kegiatan pada pasien harga diri rendah di Rumah Sakit Jiwa Dr. Soeharto Heerdjan Jakarta dengan $p$ value .000 ( $\mathrm{p}<0,05)$ maka dikatakan Ha diterima dan Ho ditolak, terapi kreasi seni menggambar sangat 
bermanfaat bagi pasien dengan gangguan harga diri rendah karena dapat memancing stimulus pasien untuk mengingat aspek positif yang dimiliki serta dapat melakukan kegiatan secara mandiri dan pasien dapat menggambar bentuk yang dipilih olehnya karena setiap gambar mempunyai arti untuk dapat melakukan kegiatan secara mandiri namun hal tersebut harus dibarengi applause dengan reward untuk pasien.

\section{Kesimpulan}

Kemampuan melakukan kegiatan pasien harga diri rendah sebelum diberikan terapi kreasi seni menggambar sebagian besar tidak mampu melakukan kegiatan SP I karena klien belum memahami kegiatan apa dan gambar apa yang ingin dibuat.

Kemampuan melakukan kegiatan pasien harga diri rendah sesudah diberikan terapi kreasi seni menggambar sebagian besar mampu melakukan kegiatan SP I karena klien sebagian besar memahami kegiatan apa dan gambar apa yang ingin dibuat dan dapat menidentifikasi gambar yang mudah dibuat.

Pengaruh kreasi seni menggambar terhadap kemampuan melakukan kegiatan berdasarkan arti dari menggambar bentuk pada pasien harga diri rendah di rsj dr. soeharto heerdjan jakarta.

\section{Saran}

Diharapkan penelitian ini dapat digunakan sebagai informasi tambahan bagi perawat dalam memberikan terapi kreasi seni menggambar yang tepat dan benar sesuai dengan kelompok pasien sehingga dapat membantu pasien untuk melakukan kegiatan serta terapi kreasi seni menggambar sangat bermanfaat bagi pasien dengan gangguan harga diri rendah karena dapat memancing stimulus pasien untuk mengingat aspek positif yang dimiliki serta dapat melakukan kegiatan secara mandiri namun hal tersebut harus dibarengi dengan reward untuk pasien.

Diharapkan penelitian ini dapat meningkatkan hubungan yang baik antara perawat - pasien agar tercipta suasana yang aman dan nyaman bagi pasien dan dapat membantu pasien belajar melakukan kegiatan, sehingga dapat meningkatkan harga diri pasien dan berguna bagi orang lain serta membuat pasien lebih terbuka tentang apa yang sedang dirasakan dan dialaminya
Hasil penelitian dapat memberikan pengetahuan dan informasi tentang terapi kreasi seni menggambar dan diharapkan pelaksanaan terapi kreasi seni menggambar menjadi salah satu terapi modalitas rutin dan membudaya di Rumah Sakit Jiwa Dr. Soeharto Heerdjan Jakarta.

\section{Daftar Pustaka}

1. Maramis, W.F. Catatan ilmu kedokteran jiwa, Cetakan kesembilan. Surabaya: Airlangga University Press; 2005.

2. Stuart, Gail W. Buku saku keperawatan jiwa (Ed. 5). Kapoh, R.P \& Yudha, E.K. Penerjemah. Jakarta: EGC; 2007.

3. Yoseph. Sistem Neurobehaviour. Jakarta: Salemba Medika; 2010.

4. Nasir, Abdul, \& Muhith, Abdul. Dasar-dasar keperawatan jiwa. Jakarta : Salemba Medika; 2011.

5. Ruspawan. Gambaran melakukan kegiatan pada klien dengan harga diri rendah sebelum diberikan terapi kreasi seni Menggambar. Skripsi. Tidak dipublikasikan. Jakarta: Fakultas Ilmu Keperawatan Universitas Airlangga; 2011.

6. Rekam Medis RSJ dr. Soeharto Heerdjan Jakarta Tahun 2016. Tidak dipublikasikan

7. Sugiyono, A. Pengaruh terapi suportif terhadap kemampuan bmelakukan kegiatan pada pasien harga diri rendah di Rumah Sakit Jiwa Daerah Dr. Amino Gondohutomo semarang. Tesis. Tidak Dipublikasikan. Jakarta: Fakultas Ilmu Keperawatan Universitas Indonesia; 2007.

8. Hasriana. Pengaruh terapi lingkungan terhadap kemampuan pasien bersosialisasi pada klien isolasi sosial menarik diri di rumah sakit khusus daerah provinsi sulawesi selatan. Tesis. Tidak dipublikasikan. Makassar: Fakultas Ilmu Keperawatan Universitas Hasanudin;2011.

9. Yundini. Metodoogi Penelitian Keperawatan dan Teknik Analisis Data. Jakarta: Salemba medika; 2007.

10. Stanley, B., Erb., Blais, K, Berman, A., Synder, S.J. Fundamental keperawatan: konsep, proses dan praktik (Ed 7). Esty W., Devi Y., \& Ana L., Penerjemah). Jakarta: EGC; 2011.

11. Setyoadi \& Kushariyadi. Terapi modalitas keperawatan pada klien psikogeriatrik. Jakarta: Salemba Medika; 2011.

12. Kementrian Kesehatan RI (2013). Riset kesehatan dasar. www.litbang.go.id. Diakses tanggal 30 juli 2016 Jakarta :Depkes RI

13. Nugroho. Konsep dan penerapan metodologi penelitian ilmu keperawatan, pedoman skripsi, tesis dan instrument penelitian keperawatan. Jakarta: Salemba Medika; 2013.

14. Keliat,dkk. Keperawatan kesehatan jiwa komunitas. CMHN basic course. Jakarta: EGC; 2011. 
15. Suknada. pengaruh pelaksanaan terapi menggambar kelompok stimulasi sensori terhadap kemampuan respon melakukan kegiatan pada pasien harga diri rendah di RSJ Provinsi Bali._Skripsi. Tidak dipublikasikan. Bali: Fakultas Ilmu Keperawatan Universitas Denpasar; 2010.
16. Surtiningrum. Buku ajar keperawatan jiwa (Ed. 4). (Renata Komalasari \& Afrina Hany. Penerjemah). Jakarta: EGC; 2008. 